\title{
MODALITY EXPRESSED BY WILL AND WOULD IN LEGAL TEXTS AND THEIR EQUIVALENTS IN ROMANIAN Roxana Petruţa GOGA-VIGARU
}

\author{
"Spiru Haret" University, Craiova, Romania \\ roxanavigaru@yahoo.com
}

\begin{abstract}
Modality is influenced by different genres and finding the types of modality commonly found in legal texts is the goal of the present paper. Modals are very important because they involve communication about advice, about obligation or permission and they also help us to express our decisions about what we think, about what we know and how strongly we believe that our knowledge is correct. The present study deals with the uses of 'will' and 'would' in legal texts and the comparison with their Romanian counterparts in point of epistemic and deontic modalities.
\end{abstract}

\section{Keywords: modality, epistemic, deontic, equivalence, translation}

\section{Introduction}

The present study deals with the uses of will and its past equivalent would in point of deontic and epistemic values and seeks to establish areas of similarity and contrast between English and Romanian. The research methodology involves a qualitative analysis complemented by a quantitative approach which proves to be very useful when measuring the preference of translators for rendering will and would into Romanian. The corpus was selected from the electronic database EUR-lex and consists of 29,900 word legal texts [1].

\section{The analysis of will in legal texts}

Will appears eight times in the corpus with two functions: indicating futurity and denoting constraint and concerning the epistemic and deontic modalities, in four of its occurrences it is being used with deontic value and in the remaining four with epistemic value. The sentences from the corpus where will is used with epistemic value may be called predictions; these inferences concerning a future state of affairs make us realize that "our knowledge of the future is nothing more than our understanding and attitude towards the modalities of the present" [2]:

(1) a. "The NUTS level 2 regions which would have been eligible for Convergence objective status under Article 5(1) had the eligibility threshold remained at $75 \%$ of the average GDP of the EU-15, but which lose eligibility because their nominal GDP per capita level will exceed $75 \%$ of the average GDP of the EU-25, measured and calculated according to Article 5(1) shall be eligible, on a transitional and specific basis, for financing by the Structural Funds under the Convergence objective."

b. "The NUTS level 2 regions totally covered by Objective 1 in 2006 under Article 3 of Regulation (EC) No 1260/1999 whose nominal GDP level per capita, measured and calculated according to Article 5(1) will exceed $75 \%$ of the average GDP of the EU 15, shall be eligible on a transitional and specific basis, for financing by the Structural Funds under the Regional competitiveness and employment objective." 
In the above examples, will is very close to expressing certainty and it expresses the speaker's present assessment of the probability and predictability of a future state of affairs. In the following example where it is used with epistemic value, will is also very close to expressing certainty, although the inference can only be verified in the future:

(2) "The Member States eligible for funding from the Cohesion Fund in 2006 which would have continued to be eligible had the eligibility threshold remained at $90 \%$ of the average GNI of the EU-15, but which lose eligibility because their nominal per capita GNI will exceed $90 \%$ of the average GNI of the EU-25 measured and calculated according to Article 5(2), shall be eligible on a transitional and specific basis, for financing by the Cohesion Fund under the Convergence objective."

Concerning the deontic values of will in our corpus, the following examples may be analyzed, where the appearances of will may be explained as expressing intention or willingness:

(3) a. "For those programmes, The Commission may conclude that it can rely principally on the opinion referred to in Article 62(1) (d) (ii) with regard to the effective functioning of the systems and that it will carry out its own on-the-spot audits only if there is evidence to suggest shortcomings in the system affecting expenditure..."

b. "(b)... the Commission may conclude that it can rely principally on the opinion referred to in Article 62(1) (d) (ii) with regard to the effective functioning of the systems and that it will carry out its own on-the-spot audits only if there is evidence to suggest that shortcomings in the system affecting expenditure certified to the Commission..."

A new meaning may be brought to light through a thorough analysis of the occurrences of will in these contexts, so the intention is transformed into the determination of the Commission to perform or bring about a state of affairs, i.e. to carry out its own on-the-spot audits.

\section{The analysis of would in legal texts}

In this section, would is analyzed as having epistemic meaning, in two of its occurrences marking the 'irrealis'. For a better understanding of the terms 'realisirrealis', we should take a look at M. Mithun's definition: The realis portrays situations as actualized, as having occurred or actually occurring, knowable through direct perception. The irrealis portrays situations as purely within the realm of thought, knowable only through imagination [3].

The two occurrences of would marking the 'irrealis' involve a certain remoteness from reality:

(4) a. "The NUTS level regions which would have been eligible for Convergence objective status under Article 5(1) had the eligibility threshold remained at $75 \%$ of the average GDP of the EU-15, but which lose eligibility because their nominal GDP per capita level will exceed $75 \%$ of the average GDP of the EU-25, measured and calculated according to Article 5(1)..."

b. "The Member States eligible for funding from the Cohesion Fund in 2006 which would have continued to be eligible had the eligibility threshold remained at $90 \%$ of the average GNI of the EU-15, but which lose eligibility because their nominal per capita GNI will exceed $90 \%$..."

Here, would indicates tentativeness, improbable facts and these sentences describe a past unfulfilled situation since in both of them would is followed in the apodosis by the complement verb in the perfect infinitive ('would have been eligible', 'would have continued').

\section{The Romanian equivalents of will}

In this section, the choice of equivalents of will is rendered through examples of its Romanian counterparts and the analysis of the Romanian corpus shows that the present tense of the verb is the equivalent in the majority of its occurrences and the future tense in only one appearance. 
After a thorough analysis, we notice that, while in English the inference can only be verified in the future, in Romanian the occurrence of will expresses the speaker's present assessment of the probability of a present state of affairs. So, as it happens in the examples below, the present is possible instead of the future, as proved by the choice of the translator:

(5) a. "The NUTS level 2 regions totally covered by Objective 1 in 2006 under article 3 of Regulation (EC) No 1260/1999 whose nominal GDP level per capita, measured and calculated according to Article 5(1), will exceed $75 \%$ of the average GDP of the EU 15..."

b. "Regiunile de nivel NUTS 2 incluse în totalitate în obiectivul nr. 1 in 2006[...] al căror PIB nominal pe cap de locuitor, măsurat şi calculat în conformitate cu articolul 5 alineatul (1), depăşeşte PIB-ul mediu..."

(6) a. "The Member States eligible for funding from the Cohesion Fund in 2006 which would have continued to be eligible had the eligibility threshold remained at $90 \%$ of the average GNI of the EU-15, but which lose eligibility because their nominal per capita GNI will exceed $90 \%$ of the average GNI..."

b. "Statele membre eligibile pentru o finanţare din Fondul de coeziune în 2006 şi care ar fi fost eligibile în cazul în care pragul de eligibilitate ar fi rămas la $90 \%$ din VIB-ul mediu pentru Uniunea Europeană cu 15 membri, dar care nu mai sunt eligibile deoarece VIB-ul nominal pe cap de locuitor depăşeşte 90\% din VIB-ul mediu."

(7) a. "...a description of how the expenditure for the Convergence and Regional competitiveness and employment objectives will contribute to the European Union priorities of promoting competitiveness and creating jobs..."

b. "...o descriere a modului în care cheltuielile în temeiul obiectivelor de convergenţă şi de concurenţă regională şi ocuparea forţei de muncă contribuie la priorităţile Uniunii Europene în materie de promovare a concurenţei şi de creare de locuri de muncă."

Thus, the texts in our corpus make frequent use of the Present Tense of the Indicative mood which is extremely suitable for expressing the generality of the facts or of the arguments presented in the documents; the Present Tense represents the best choice in the case of the definitions and amendments that they frequently contain [4].

Apart from these texts, we have an example in English where will expresses willingness, determination and the Romanian counterpart brings new light in the meaning because we may reinterpret the sentence in the following way:

(8) "...the Commission will not carry out its own on-the-spot audits unless there is evidence to suggest shortcomings in the system...";

instead of the original version:

(9) "...with regard to the effective functioning of the systems and that it will carry out its own on-the-spot audits only if there is evidence to suggest shortcomings".

since the Romanian translation is the following:

(10) “...în ceea ce priveşte funç̧ionarea eficientă a sistemelor şi că aceasta $n u$ efectuează controale proprii la faţa locului decât în cazul în care există elemente doveditoare care să sugereze lacune în sistem"

In the following example, our knowledge of the future depends on the action in the present shown in the context and the Romanian counterpart of will is represented by the future tense of the relevant verb:

(11) a. "The NUTS level 2 regions which would have been eligible for the Convergence objective status under Article 5 (1) had the eligibility threshold remained at $75 \%$ of the average GDP of the EU-15, but which lose eligibility because their nominal GDP per capita level will exceed $75 \%$ of the average GDP of the EU-15..."

b. “...în cazul în care pragul de eligibilitate ar fi rămas la 75\% din PIB-ul mediu pentru 
Uniunea Europeană cu 15 membri, dar care îşi pierd eligibilitatea pentru că nivelul PIBului lor nominal pe cap de locuitor $v a$ depăşi 75\% din PIB-ul mediu..."

\section{The Romanian equivalents of would}

This section analyses the choice of translation of would in our corpus and the extent to which it is rendered in Romanian through different corresponding equivalents. As mentioned earlier, would occurs four times with epistemic meaning and it is rendered in Romanian through the present conditional and perfect conditional of the corresponding verb.

In the following examples, would expresses a hypothesis with reference to present and it is expressed in Romanian by the present conditional mood:

(12) a. "'irregularity': any infringement of a provision of Community law resulting from an act or omission by an economic operator which has, or would have, the effect of prejudicing the general budget of the European Union."

b. “'neregularitate' înseamnă orice încălcare a unei dispoziţii a dreptului comunitar care rezultă dintr-un act sau dintr-o omisiune a unui operator economic care are sau ar putea avea ca efect un prejudiciu la adresa bugetului general al Uniunii Europene..."

(13) a. "... No amount shall be deducted or withheld and no specific charge or other charge with equivalent effect shall be levied that would reduce these amounts for the beneficiaries."

b. “...Nu se procedează la nici un fel de deducere sau reţinere şi nici la vreun fel de taxă specifică sau cu efect echivalent care ar reduce sumele datorate beneficiarilor."

In the examples above, through the mood of unreality, i.e. 'would have the effect', 'would reduce', there is indicated the dissociation from reality.

As for the other two occurences of would, they involve a hypothetical condition on which a resulting hypothetical state of affairs depends. As stated by Palmer (1990: 170), the interpretation is determined by the choice of tense, as the uses of perfect conditional in both versions, English and Romanian, help us trace the similarities between them [5].

(14) a. "The Member States eligible for funding from the Cohesion Fund in 2006 which would have continued to be eligible had the eligibility threshold remained at $90 \%$ of the average GNI of the EU-15, but which lose eligibility because their nominal per capita GNI will exceed 90\%."

b. "Statele membre eligibile pentru o finanţare din Fondul de coeziune în 2006 şi care ar fi fost eligibile în cazul în care pragul de eligibilitate ar fi rămas la $90 \%$ din VIB-ul mediu pentru Uniunea Europeană cu 15 membri, dar care nu mai sunt eligibili deoarece nivelul VIB-ului nominal pe cap de locuitor depăşeşte $90 \%$..."

\section{Interpretation of the data}

An interesting finding of our analysis is the fact that concerning the epistemic meanings of will, the scale of modals ranges from doubt to certainty, while in its deontic meanings it expresses intention or willingness. Concerning the values of would, it is used with epistemic meaning marking the 'irrealis' or the tentativeness.

Another interesting result is the fact that even though will is used with epistemic value expressing futurity in English, it is translated differently into Romanian in the sense that, in English, two sentences may be considered as predictions since they state that certain actions will happen in the future while in Romanian, in one of them, the present tense is possible instead of the future. Would seems to cause no problems regarding its translation into Romanian since the perfect conditional and present conditional of the corresponding verb are equally embraced in translation. 


\section{References}

[1] Council Regulation (EC) No. 1083/2006 of July 2006/Regulamentul (CE) Nr. 1083/2006 al Consiliului din 11 iulie 2006.

[2] Bâră, Elena, Aspects of Modality in English, Bucureşti: TUB, 1979.

[3] Mithun, M., "On the Relativity of Irreality" In: Bybee, J. \& Fleischman, S. (Eds.) Modality in Grammar and Discourse, Amsterdam/Philadelphia: John Benjamins, 1995

[4] Cozma, M., Translating legal-administrative discourse. The EU Legislation, Timisoara: Ed. Universităţii de Vest, 2006

[5] Palmer, F.R., Modality and the English Modals. London: Longman, 1979/1990

[6] Official Journal of the European Union: http://eur-lex.europa.eu 